\section{Improving impregnation properties of fir wood to acid copper chromate (ACC) with microwave pre-treatment}

\author{
Milad Ramezanpour ${ }^{(1)}$, Asghar Tarmian ${ }^{(2)}$, Hamid Reza Taghiyari ${ }^{(3)}$
}

Effects of microwave pre-treatment on impregnation properties in fir wood (Abies alba L.) with acid copper chromate (ACC) were studied here. Flat-sawn specimen boards were prepared with moisture content $(\mathrm{MC})$ of $40 \pm 5 \%$ and were exposed to microwave radiation with $2450 \mathrm{MHz}$ frequency for $10,12,14$, and 16 minutes at four different radiation treatments. Microwave-treated specimens, along with the control specimens, were conditioned to the final MC of $12 \%$ and then impregnated with $5 \%$-ACC solution, using an empty-cell process. The impregnation properties were then measured, including retention, maximum and minimum depths of penetration, impregnated area in the cross-section, and ACC-leaching. Image J software was used to determine depths of penetration. Results showed that microwave pre-treatment significantly improved all the impregnation properties, with the exception of leaching. Clear direct relation was found between the duration of microwave radiation with the properties. It can be concluded that microwave pre-treatment can be used to significantly improve impregnation properties in fir wood.

Keywords: Abies Alba, Fir Wood, Impregnation, Microwave Radiation, Pretreatment

\section{Introduction}

Species with low wood permeability, such as fir (Abies alba L.), cause many problems during the wood impregnation process with preservatives. Fir is a gymnosperm species with torus margo pit membrane; the low permeability is mainly due to the pit aspiration during drying. Different modification methods, such as steaming, mechanical incising, drilling techniques and bio-incising were tested to improve the impregnation properties of such refractory wood species (Schwarze et al. 2006, Lehringer et al. 2009, Dashti et al. 2012a). Microwave (MW) radiation is an innovative method to increase the wood permeability and thus to improve the preservative penetration in the wood of various species (Vinden et al. 2003, Brodie 2009, Torgovnikov \& Vinden 2009, Dashti et al. 2012b). Due to the high efficiency in converting electricity into microwave radia- tion, energy saving, in-depth heating of materials and reduced costs, microwave pretreatment is spreading in many industries (Torgovnikov \& Vinden 2010). The increasing effect of microwave radiation on the wood permeability was reported to be due to changes in the wood porous structure ( $\mathrm{Lu}$ et al. 1994, Zhao et al. 1998, Yu et al. 2002). Torgovnikov \& Vinden (2009) mentioned that when the microwave energy was applied to wood, the steam pressure generated within the wood cells provokes the rupture of the pit membranes on cell walls and the weak ray cells, allowing an easier fluid transfer. Liu et al. (2005) reported that the permeability of larch wood can be improved without noticeable reduction in the strength and stiffness if the conditions of microwave pretreatment were optimized. Treu \& Gjolsjo (2008) also reported that the microwave processing of Norway spruce (Picea abies L.)

$\square$ (1) Faculty of Natural Resources, University of Tehran, Tehran (Iran); (2) Department of Wood and Paper Science \& Technology, Faculty of Natural Resources, University of Tehran, Tehran (Iran); (3) Wood Science and Technology Department, Faculty of Civil Engineering, Shahid Rajaee Teacher Training University, Tehran (Iran)

@ Hamid Reza Taghiyari (htaghiyari@srttu.edu)

Received: Sep 07, 2013 - Accepted: Nov 11, 2013

Citation: Ramezanpour M, Tarmian A, Taghiyari HR, 2015. Improving impregnation properties of fir wood to acid copper chromate (ACC) with microwave pre-treatment. iForest 8 : 89-94 [online 2014-04-01] URL: http://www.sisef.it/iforest/contents/?id=ifor1119-007

Communicated by: Elena Paoletti

caused a significant increase in the uptake of a $2 \%$ copper-based preservative after wood modification by microwave energy of more than $50 \mathrm{kWh} / \mathrm{m}^{3}$ at a frequency of $2.45 \mathrm{GHz}$. Hong-Hai et al. (2005) also found that the water uptake of Larch (Larix olgensis) wood irradiated by microwave was 2.5 to 3.3 times greater than that of non-radiated wood. Dashti et al. (2012b) found that the microwave radiation of fir wood (Abies alba L.) at frequency of $2.45 \mathrm{GHz}$ for 7 and 10 minutes can increase the wood radial permeability. They also reported that the torus of some bordered pits was hydrolyzed due to the microwave radiation; however, they did not study the relationship of MW pre-treatment on the amount of preservative uptake, depth of penetration, or other impregnation properties. This species is vastly grown in different parts of the world and therefore provide a continuous raw material for commercial applications; huge amount of fir lumbers are also imported to Iran on a regular basis to satisfy the growing needs for commercial woods. Because of the importance of fir species in timber industry and its various applications, the present research was carried out to evaluate the effects of microwave radiation conditions on the impregnation properties of fir wood (Abies alba L.) with ACC (acid copper chromate) preservative.

\section{Materials and methods}

Sampling and microwave pre-treatment Ten flat-sawn boards of fir wood (Abies alba L.) with green dimensions of $400 \times 15$ $\times 5 \mathrm{~cm}$ and average moisture content (MC) of $40 \pm 5 \%$ were used for the study. From each board, five specimens were prepared; one as the control specimen without MW-radiation, and the other four specimens to be MW-radiated under four different MW-treatments. The dimensions of specimens were $250 \times 100 \times 50 \mathrm{~mm}$. Density of the specimens at moisture content of $8 \%$ was $0.32 \mathrm{~g}$ $\mathrm{cm}^{-3}$. A domestic Samsung microwave oven (CE3780AT) with frequency of $2450 \mathrm{MHz}$ was used for microwave radiation; the output power was $900 \mathrm{~W}$. Four MW-treatments were used (Tab. 1). The microwave radiation was stopped for 60 to $90 \mathrm{sec}$ (rest time) after every 60 to $150 \mathrm{sec}$ of microwave exposure to prevent cracking due to the rapid wood moisture removal. Specimens were exposed to MW one at a time. The total MW exposure times were 300, 450, 480, and $600 \mathrm{sec}$ for MW1, MW2, MW3, and MW4, respectively. Before and after the MW-radiation, specimens were weighted using a digital scale with $0.01 \mathrm{~g}$ precision, in order to measure the reduced weight. Due to hygromechanical behavior of wood (Figueroa et al. 2012), after microwave treatment the sam- 
Tab. 1 - Microwave radiation treatments applied to fir wood specimen boards (Abies alba L.).

\begin{tabular}{|c|c|c|c|c|c|c|c|}
\hline 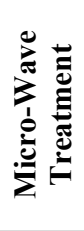 & $\sum \sum_{0}^{2}$ & 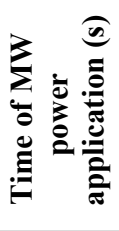 & 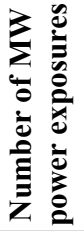 & 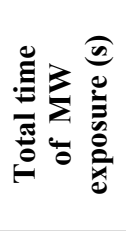 & 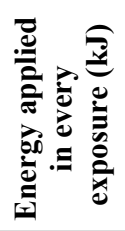 & 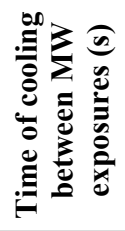 & 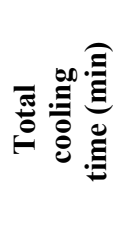 \\
\hline MW1 & 0.90 & 60 & 5 & 300 & 54 & 60 & 5 \\
\hline MW2 & 0.90 & 90 & 5 & 450 & 81 & 60 & 5 \\
\hline MW3 & 0.90 & 120 & 4 & 480 & 108 & 90 & 9 \\
\hline MW4 & 0.90 & 150 & 4 & 600 & 135 & 90 & 9 \\
\hline
\end{tabular}

ples were conditioned to $12 \%$ moisture conrature of $20^{\circ} \mathrm{C}$.

\section{Impregnation method}

Before impregnation, the samples were end coated using two layers of paraffin to prevent the preservative flow through the longitudinal direction. Samples were then impregnated with ACC, using Rueping method. The used preservative solution was a mixture of Copper Sulfate, Sodium Dichromate and Chromic Acid with concentration of $50 \%$, tent at relative humidity of $65 \%$ and tempe-
$48.3 \%$ and $1.7 \%$, respectively. The diagram of impregnation process is shown in Fig. 1.

\section{Measuring impregnation properties}

After the impregnation, the preservative retention was calculated as follows (eqn. 1):

$$
R=\frac{M_{i}-M_{n}}{V_{w}} \cdot \frac{C_{p}}{100}
$$

where $R$ (retention) is the amount of wood preservative retained in the wood specimen ( $\mathrm{kg}$ of preservative per $\mathrm{m}^{3}$ of wood), $M_{i}$ is the mass of wood specimen after impregnation $(\mathrm{kg}), M_{n}$ is the mass of wood specimen before impregnation $(\mathrm{kg}), V_{w}$ is the volume of the specimen $\left(\mathrm{m}^{3}\right)$ and $C_{p}$ is the concentration of the preservative in the impregnation solution $\left(\mathrm{kg} \mathrm{kg}^{-1}\right)$.

The depth of preservative penetration was measured using Chrome Azurol S (color index No.43825, also known as mordant blue 29) reagent according to AWPA-A3-84 standard (AWPA 1986). To prepare this reagent, $0.5 \mathrm{~g}$ Chrome Azurol S and $5 \mathrm{~g}$ sodium acetate were dissolved in $80 \mathrm{ml}$ distilled water and the solution was diluted to a volume of $300 \mathrm{~mL}$. Then, this reagent was sprayed on the cross section of impregnated specimens. As a result, ACC-impregnated areas appeared in blue color and un-impregnated surfaces changed to red color. Depth of penetration was measured at four different sides in each specimen with a digital caliper with 0.1 $\mathrm{mm}$ precision; finally, the maximum and minimum depths of penetration were determined. The impregnation area (\%) on the wood cross section was measured by the aid of the software Image J. The leaching tests were conducted based on EN-84 standard. Five specimens with dimensions of $50 \times 25$

Fig. 1 - Diagram of the impregnation method used (Rueping).

1 - initial pressure $(5 \mathrm{~min})$

2- main pressure (120 $\mathrm{min})$

3 - finally vacuum (15 $\mathrm{min}$ )

Time (min)

Vacuum 0.3
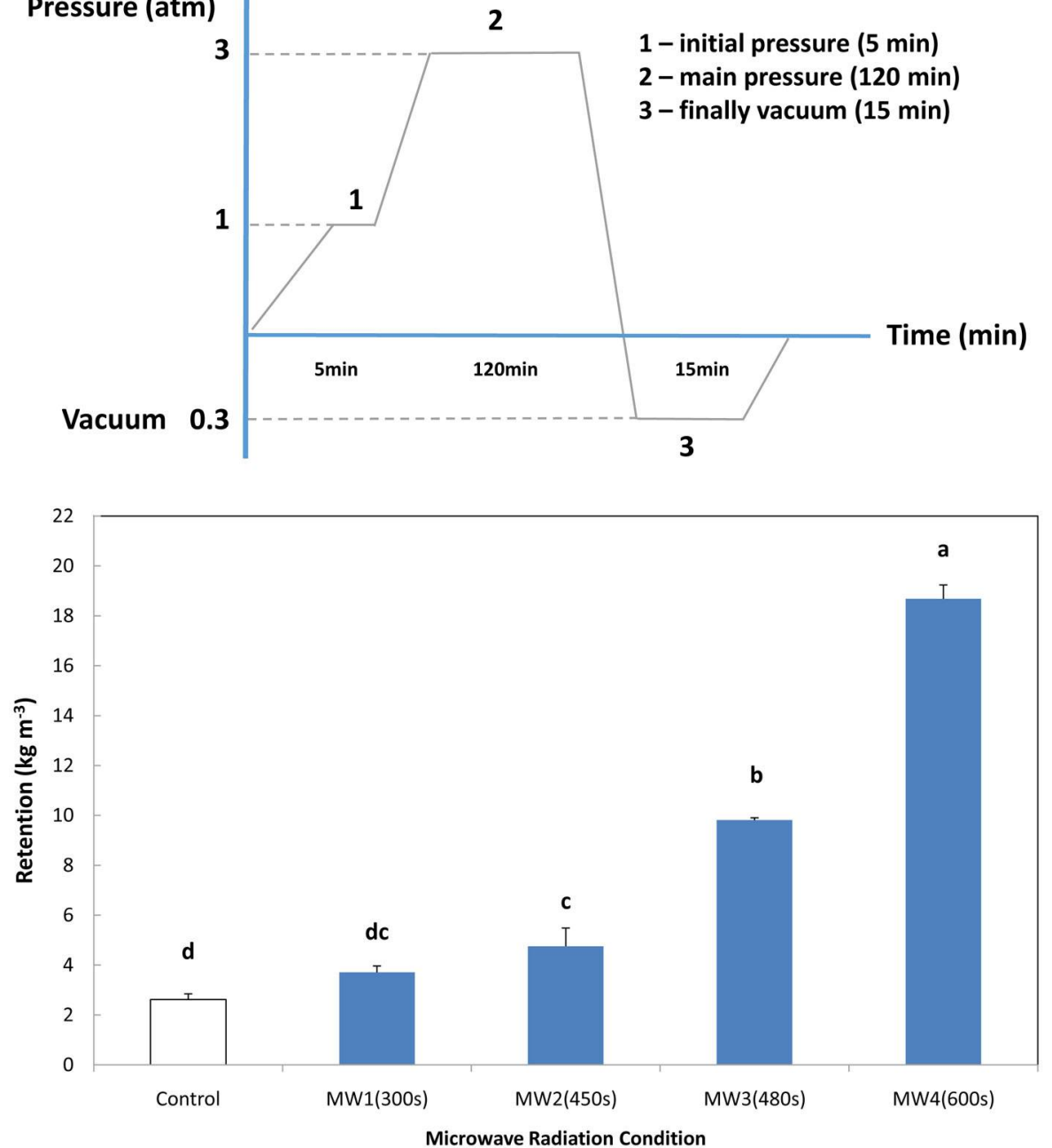

Fig. 2 - Acid Copper Chromate (ACC) retention in the microwave radiated and un-radiated wood specimens of fir wood \pm SD. Different letters indicate significant differences among the means according to Duncan's test $(\mathrm{N}=5)$. 
Fig. 3 - Maximum depth of ACC penetration $(\mathrm{mm})$ through the microwave radiated and unradiated wood specimens of fir wood $\pm \mathrm{SD}$.

Different letters indicate significant differences among the means according to Duncan's test $(\mathrm{N}=5)$.

Fig. 4 - Minimum depth of ACC penetration $(\mathrm{mm})$ through the microwave radiated and unradiated wood specimens of fir wood \pm SD. Different letters indicate significant differences among the means according to Duncan's test $(\mathrm{N}=5)$.
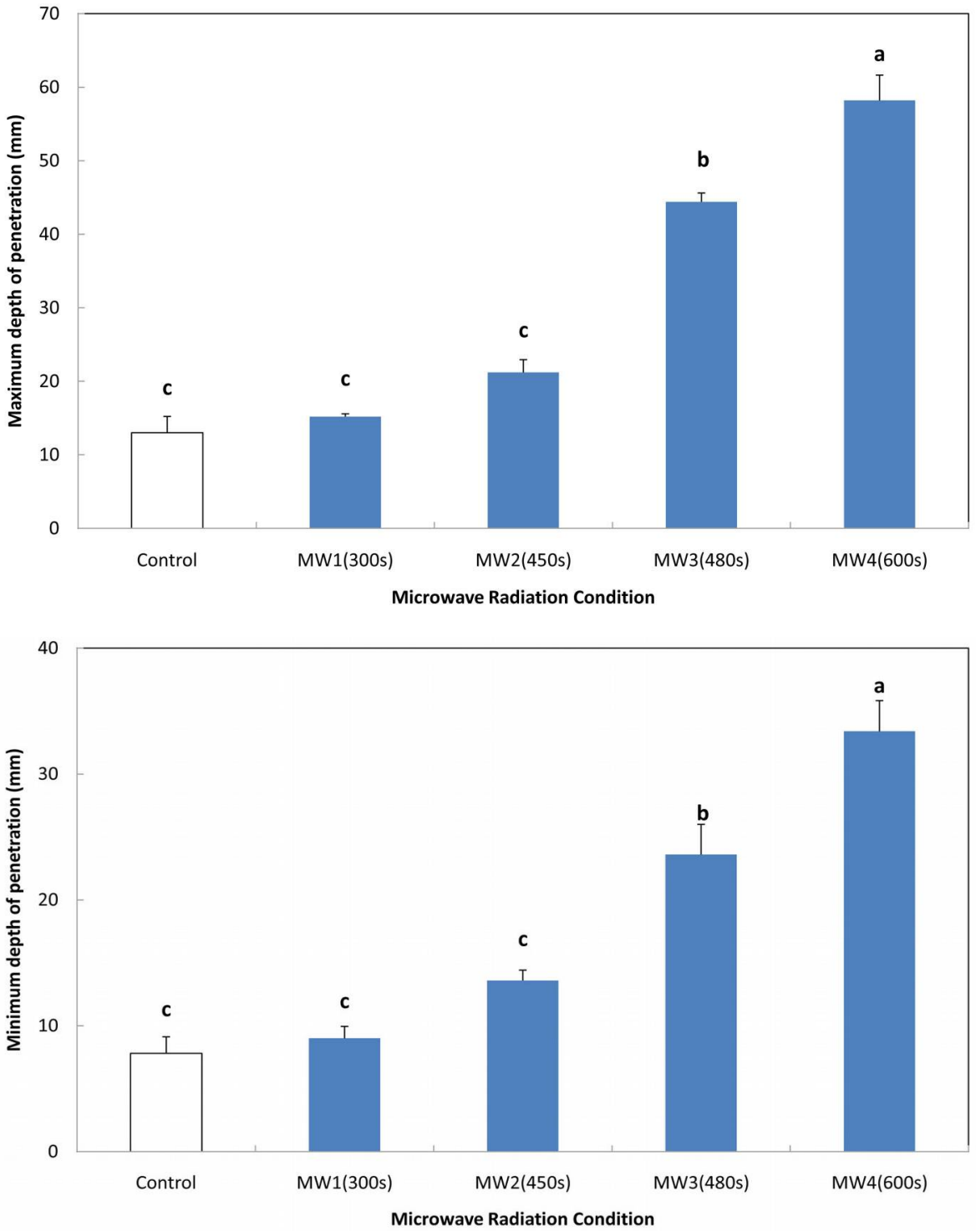

hierarchical cluster analysis was carried out using the Ward's method on a squared Euclidean distance matrix.

$\times 15 \mathrm{~mm}$ were prepared from each treatment and kept in conditioning chamber for 3 weeks (relative humidity of $65 \pm 5 \%$ at $20 \pm$ $2{ }^{\circ} \mathrm{C}$ ). Specimens were then placed in a desiccator located in separate test vessels, fitted with a vacuum pump, capable of maintaining a pressure of $4 \mathrm{kPa}$. Specimens were ballasted with weights to prevent from floating and then flooded with water. Specimen were immersed in water for 14 days. At the end of the first and second day of immersion, water was changed; water was further changed seven times in the remaining 12 days at intervals of two days. For each MWtreatment, five replications were used.

ANOVA was applied to the collected data $(\alpha=0.05)$ after their normal distribution was verified. The significance of the differences among the means of MW-treatments was tested using the Duncan's multiple range test by SPSS (v. 2011) software. To summarize the differences among MW-treatments based on more than one property simultaneously, a

\section{Results}

All the microwave treatments increased the preservative retention in the wood specimens (Fig. 2). The preservative retention was improved by increasing the microwave radiation period from 10 to 16 minutes. However, the difference between non-impregnated wood specimens and those MW-radiated for 10 min was not statistically significant. The preservative retention for the specimens MW-radiated for 16 min was outstanding and ranged from 16.55 to $19.56\left(\mathrm{~kg} \mathrm{~m}^{-3}\right)$. The retention of 16 min MW-radiated specimens was improved by almost 7 times (612\%) compared to that for the un-radiated ones. The preservative retention for non-impregnated wood specimens ranged from 1.74 to $2.98\left(\mathrm{~kg} \mathrm{~m}^{-3}\right)$.

The preservative penetration through the wood specimens was improved due to microwave exposure and the improvement was remarkable for the samples that were MWradiated for 14 and 16 min (Fig. 3, Fig. 4). The average maximum depth of preservative penetration at $16 \mathrm{~min}$ of radiation was 58.2 $\mathrm{mm}$ compared to $13 \mathrm{~mm}$ for the un-radiated specimens. The minimum depth of penetration was also improved by almost 4 times $(328 \%)$ as a result of microwave radiation for $16 \mathrm{~min}$.

Preservative penetrated along the ray cells easily reached the central parts of the MWradiated specimens (Fig. 5). In the control specimens though, no penetration along the ray cells was observed. The significant effect of MW-radiation on penetration of preservative to the central parts of specimens was quite obvious through the measurement of the impregnated area on the cross-sections of specimens (Fig. 6); the impregnated area was the lowest in the control specimens in comparison to other treatments. 

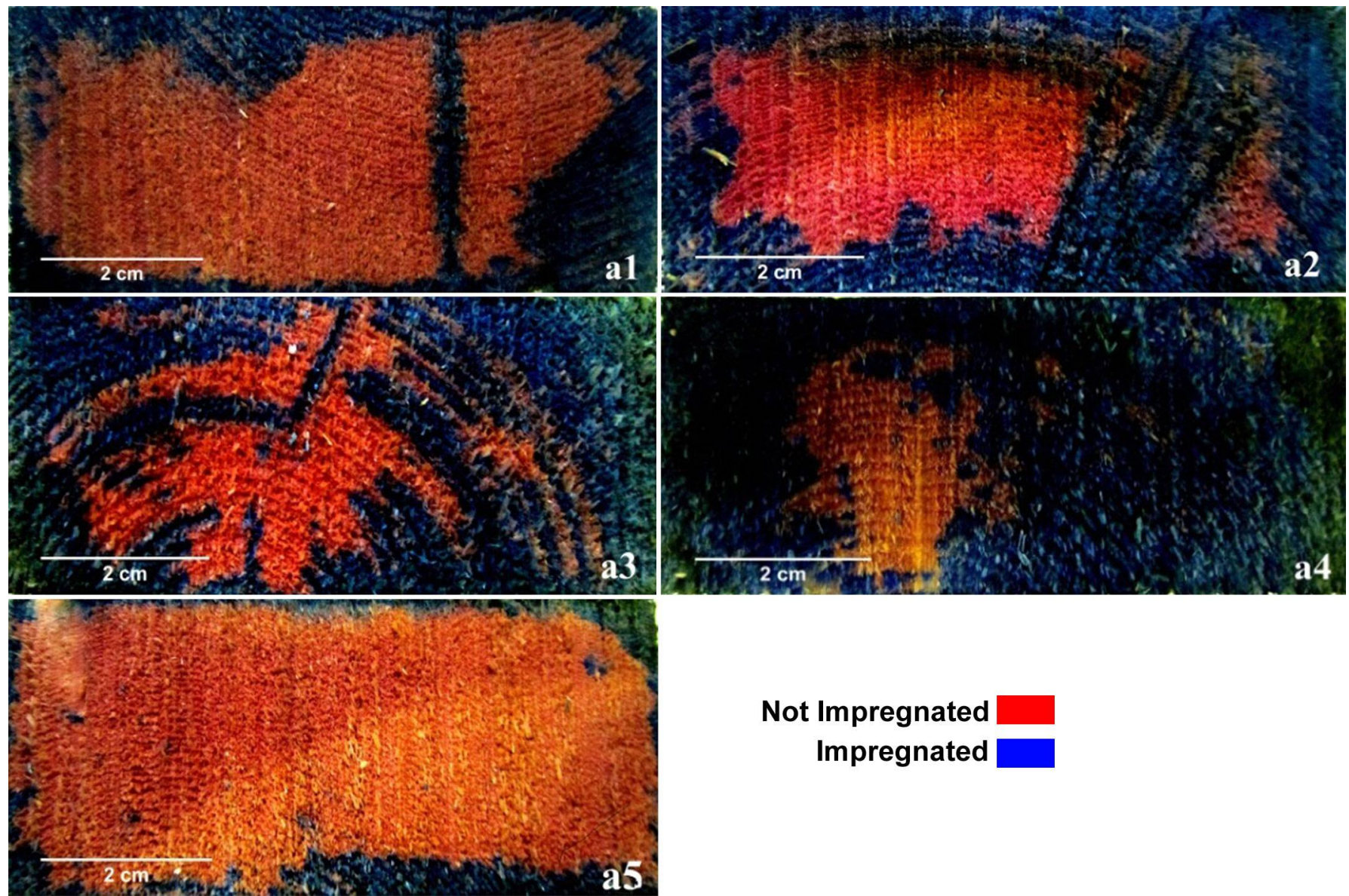

\section{Not Impregnated Impregnated}

Fig. 5 - Cross-section of impregnated samples, (a1): MW1; (a2): MW2; (a3): MW3; (a4): MW4; (a5): control.

There was no significant difference in the leaching of ACC preservative between MWradiated and un-radiated specimens (Fig. 7) However, the amount of leaching tended to decrease as the MW-energy increased (refer to Tab. 1). The lowest leaching were observed in MW3 and MW4, although not significantly different from other MW-radiated or the control specimens. The increase in MW also increased the amount of the reduced weight (Fig. 8). In fact, the reduced weight increased as the MW-energy increased. The highest reduced weights were observed in MW3 and MW4 treatment.

Cluster analysis, based on all the impregnation properties measured in the present study

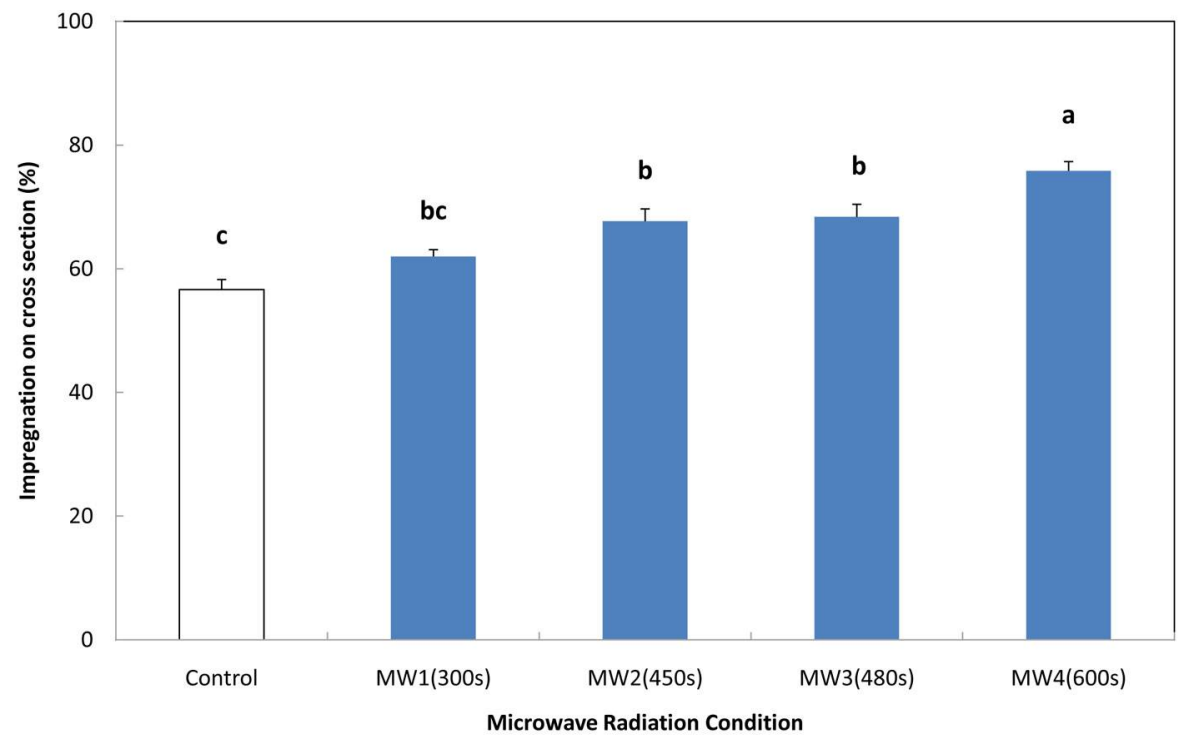

(retention, maximum and minimum depths of penetration, impregnated area in the cross-section, and ACC leaching) showed that microwave pre-treatments for 14 and 16 minutes were significantly grouped (Fig. 9), while pre-treatments of 10 and 12 minutes were closely clustered to the control specimens.

Fig. 6 - Impregnated area (\%) measured at the cross-sectional view of the specimens cut from the middle $\pm \mathrm{SD}$. Different letters indicate significant differences among the means according to Duncan's test ( $\mathrm{N}=5)$. 
Fig. 7 - ACC leaching from the microwave radiated and un-radiated wood specimens of fir wood \pm SD. Different letters indicate significant differences among the means according to Duncan's test $(\mathrm{N}=5)$.

Fig. 8 - Reduction in the weight of specimens after the microwave radiation in comparison to their initial weight (before MW-radiation) \pm SD. Different letters indicate significant differences among the means according to Duncan's test $(\mathrm{N}=5)$.

Fig. 9 - Cluster analysis of different treatments based on all the impregnation properties \pm SD (retention, maximum and minimum depths of penetration, impregnated area in the cross-section, and ACC leaching).

\section{Discussion}

The retention of 16 min MW-treated specimens was improved by almost 7 times compared to that of the un-radiated ones. This improving effect caused by MW-treatment was also reported by Treu \& Gjolsjo (2008) for Norway spruce (Picea abies). Hong-Hai et al. (2005) also found that the water uptake of Larch (Larix olgensis) wood radiated by microwave was 2.5 to 3.3 times greater than that of the un-radiated wood. The effect of MW on the preservative retention can be attributed to ray cell rupture. The effect of
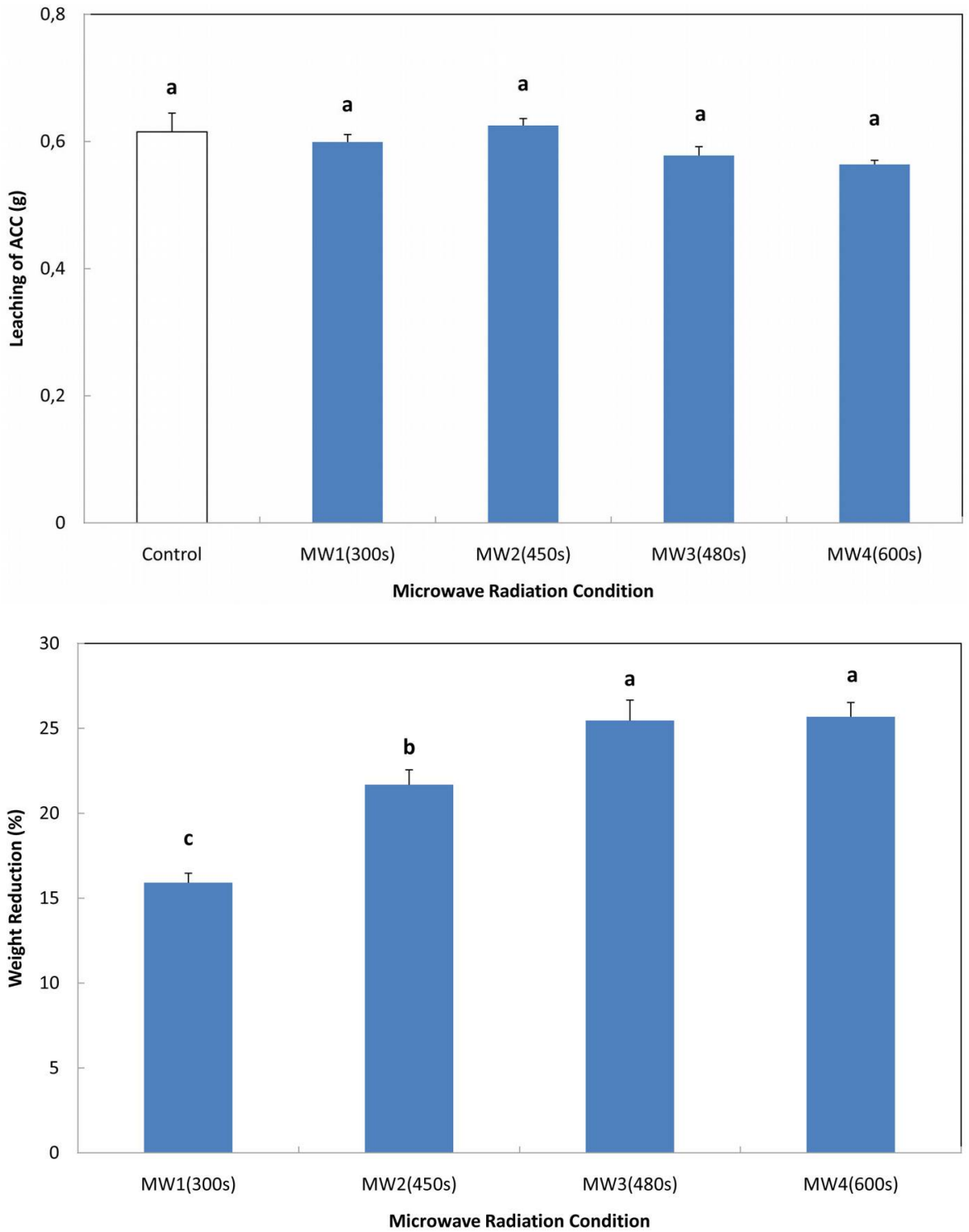

Dendrogram using Ward Method, Rescaled Distance Cluster Combine

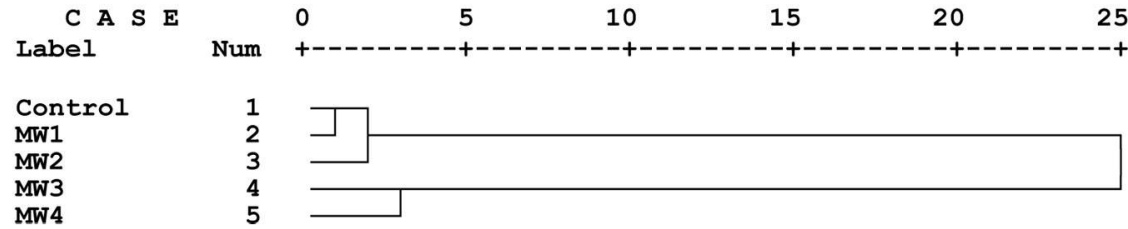

MW on preservative penetration can also be attributed to a radial wood permeability improvement as reported by Dashti et al. (2012b). The ruptures in the ray parenchyma caused by the microwave radiation facilitated the penetration of preservative. In fact, penetration of any kinds of fluid into a porous media is directly related to its structure (Taghiyari 2013); therefore, any small alterations in the porous structure by pressure (Taghiyari 2012), heat (Ghorbani et al. 2012), or cold (Taghiyari et al. 2012) would significantly change the permeation proper- ties. Moreover, the maximum weight reduction by microwave treatment occurred in MW4; consequently, it can be inferred that the maximum shrinkage and widening of pits was also happened in this treatment. Ultimately, this widening of pits resulted in a significant improvement in penetration of ACC. The radial permeability of softwood is significantly controlled by ray parenchyma rather than by bordered pits (Tarmian \& Perre 2009). Previous studies have shown that the permeability of some wood species in the radial direction can be increased by 
170-1200 times due to microwave radiation (Torgovnikov \& Vinden 2000). Results of Image $\mathrm{J}$ software studies also showed that the impregnation amount on the cross section increased due to microwave radiation; the greatest improvement was observed for specimens radiated for $16 \mathrm{~min}$.

Results of the present study showed that the effect of microwave pre-treatments on leaching of ACC as a water-based preservative was not statistically significant. However, the increasing effects of microwave post-treatment on leaching resistance of copper-based preservatives were previously reported (Zhang \& Kamdem 2000, Cao \& Kamdem 2004, Yu et al. 2010). Therefore, further complementary studies should be done to understand these contradictions. In the meantime, a fixation method is recommended to be applied to prevent the preservative from leaching.

Cluster analysis, based on all the impregnation properties measured in the present study showed that microwave pre-treatments for 14 and 16 minutes were significantly grouped. So, from an economical point of view, microwave pre-treatment of 14 minutes may be recommended due to the shorter time and thus lower costs. Furthermore, pre-treatments of 10 and 12 minutes were closely clustered to the control specimens. It can then be concluded that these two exposure time may not be recommended. As the difference between MW2 and MW3 was only 2 minutes, it may be concluded that the critical point was between 12 and $14 \mathrm{~min}$ of $\mathrm{mi}$ crowave exposure. Further studies on optimal time-intervals as well as on mechanical properties are recommended.

\section{References}

AWPA (1986). AWPA Book of Standards. American Wood Protection Association, Maryland, USA. [online] URL: http://www.awpa.com/index.asp

Brodie G (2009). Innovative wood drying: applying microwave and solar technologies to wood drying. VDM Verlag, Saarbrucken, Germany, pp. 120.

Cao JZ, Kamdem DP (2004). Microwave treatment to accelerate fixation of copper ethanolamine (Cu-EA) treated wood. Holzforschung 58: 569-571. - doi: 10.1515/HF.2004.087

Dashti H, Tarmian A, Faezipour M, Hedjazi S, Shahverdi M (2012a). Effect of pre-steaming on mass transfer properties of fir wood (Abies alba L.): a gymnosperm species with torus margo pit membrane. BioResources 7: 1907-1918.

Dashti H, Tarmian A, Faezipour M, Hedjazi S, Shahverdi M (2012b). Effect of microwave radiation and pre-steaming treatments on the conventional drying characteristics of fir wood (Abies alba L.). Lignocellulose 1: 166-173. [online] URL: http://lignocellulose.ir/issue.htm

Figueroa M, Bustos C, Dechent P, Reyes L, Cloutier A, Giuliano M (2012). Analysis of rheological and thermo-hygro-mechanical behavior of stress-laminated timber bridge deck in variable environmental conditions. Maderas Ciencia y tecnologia 14 (3): 303-319.

Hong-Hai L, Qing-Wen W, Lin Y, Tao J, YingChun C (2005). Modification of larch wood by intensive microwave irradiation. Journal of Forestry Research 16 (3): 237-240. - doi: 10.1007/ BF02856823

Ghorbani M, Akhtari M, Taghiyari HR, Kalantari A (2012). Effects of silver and zinc-oxide nanoparticles on gas and liquid permeability of heat-treated Paulownia wood. Austrian Journal of Forest Science 129 (2): 106-123.

Lehringer C, Arnold M, Richter K, Schubert M, Schwarze F, Militz H (2009). Bio incised wood as substrate for surface modifications. In: Proceedings of the " 4 th European Conference on Wood Modification" (Englund F, Hill CAS, Militz H, Segerholm BK eds). Stockholm (Sweden) 27-29 May 2009, pp. 197-200.

Liu H, Wang Q, Yang L, Jiang T, Cai Y (2005). Modification of larch wood by intensive microwave irradiation. Journal of Forestry Research 16: 237-240. - doi: 10.1007/BF02856823

Lu J, Bao F, Jiang X, Zhou M (1994). Effect of steaming on the permeability of wood. Scientia Silvae Sinicae 30: 352-357. [online] URL: http://en.cnki.com.cn/Article en/CJFDTOTAL-L YKE404.010.htm

Schwarze FWMR, Landmesser H, Zgraggen B, Heeb M (2006). Permeability changes in heartwood of Picea abies and Abies alba induced by incubation with Physisporinus vitreus. Holzforschung 60: 450-454. - doi: 10.1515/HF.2006.0 71

Taghiyari HR (2012). Correlation between gas and liquid permeabilities in some nanosilver-impregnated and untreated hardwoods. Journal of Tropical Forest Science 24 (2): 249-255.

Taghiyari HR, Layeghi M, Aminzadeh Liyafooee F (2012). Effects of dry ice on gas permeability of nano-silver-impregnated Populus nigra and Fagus orientalis. IET Nanobiotechnology 6 (2):
40-44. - doi: 10.1049/iet.nbt.2011.0048

Taghiyari HR (2013). Effects of heat-treatment on permeability of untreated and nanosilver-impregnated native hardwoods. Maderas - Ciencia y tecnología 15 (2): 183-194. - doi: 10.4067/S07 18-221X2013005000015

Tarmian A, Perre P (2009). Air permeability in longitudinal and radial directions of compression wood of Picea abies L. and tension wood of $\mathrm{Fa}$ gus sylvatica L. Holzforschung 63: 352-356. doi: 10.1515/HF.2009.048

Torgovnikov G, Vinden P (2000). New wood based materials TORGVIN and VINTORG. In: Proceedings of the " 5 th Pacific Rim Bio-Based Composite Symposium". Canberra (Australia) 10-13 December 2000. Australian National University, Canberra, Australia, pp. 756-764.

Torgovnikov G, Vinden P (2009). High-intensity microwave wood modification for increasing permeability. Forest Products Journal 59: 84-92.

Torgovnikov G, Vinden P (2010). Microwave wood modification technology and its applications. Forest Products Journal 60:173-182. - doi: 10.13073/0015-7473-60.2.173

Treu A, Gjolsjo S (2008). Spruce impregnation, finally a breakthrough by means of microwave radiation In: Proceedings of the "4th Meeting of the Nordic Baltic Network in Wood Material Science \& Engineering (WSE)”. Riga (Latvia) 13-14 Nov 2008. SNS-Nordic Forest Research Co-operation Committee, Copenhagen University, Horsholm, Denmark, pp. 42-48.

Vinden P, Romero J, Torgovnikov G (2003). A method for increasing the permeability of wood. US patent 6: 596-975.

Yu ZM, Zhao L, Li WJ (2002). Study on permeable mechanism with dyestuff during wood dyeing. Journal of the Beijing Forest University 24: 79-82.

Yu LL, Gao W, Cao JZ Tang ZZ (2010). Effects of microwave post-treatments on leaching resistance of ACQ-D treated Chinese fir. Forestry Studies in China 12 (1): 1-8. - doi: 10.1007/s11 632-010-0008-3

Zhang J, Kamdem DP (2000). Interaction of copper-amine with southern pine: retention and migration. Wood and Fiber Science 32: 332-339. [online] URL: http://swst.metapress.com/content/f4781225x27lr2r8/

Zhao H, Turner IW, Torgovnikov G (1998). An experimental and investigation of the microwave heating of wood. The Journal of Microwave Power and Electromagnetic Energy 33 (2): 121133. 